\title{
Notes on veliids from Venezuela, with the description of a new Microvelia (Hemiptera)
}

By

\section{John T. POLHEMUS}

3115 S. York, Englewood, Colo., USA 80110

\section{With 1 figure}

\section{Abstract}

A small sample of veliids from the Cueva Alfredo Jahn Miranda, Venezuela, contained Rhagovelia sinuata Gould and Microvelia cavernula $\mathrm{n}$. $\mathrm{sp}$.

Through the kindness of Dr. Bernd Hauser of the Museum of Natural History of Geneva I have been permitted to study a small collection of veliids from the Cueva Alfredo Jahn Miranda in Venezuela.

This collection contained two species of veliids including a new Microvelia described below.

I am indebted to Dr. R. C. Froeschner for furnishing information concerning material held in the Drake Collection of the Smithsonian Institution.

For all measurements given in units, 60 units equals $1 \mathrm{~mm}$.

\section{Rhagovelia sinuata Gould}

Rhagovelia sinuata Gould 1931. Kans. Univ. Sci. Bull. 20: 42 (type locality, Ecuador).

BACON (1956) listed this species from Ecuador and Peru, but recently I have 
examined specimens from Trinidad and Surinam, thus its occurrence in Venezuela is not surprising.

Material examined: 1 q, Venezuela, Cueva Alfredo Jahn Miranda, 21.2.1968, Bordon, Strinati.

\section{Microvelia cavernula n. sp.}

Apterous Male: Moderately long, slightly ovate, ground color yellowish brown; marked with brown dorsally on head, posterior $2 / 3$ of pronotum, lateral portions and posterior margins of tergites, genital segments; antenna, legs except for basal portions of femora, brownish; covered with fine pubescence.

Head: Convex above, median furrow inconspicuous, width across eyes $0.43 \mathrm{~mm}$, length $0.33 \mathrm{~mm}$, interocular space 15. Antennal formula I-IV, $11: 10: 16: 23$; segment 1 stout, segment 2 semi-stout, segments 3 and 4 slender; all segments with fine pubescence and longer hairs. Rostrum reaching beyond front coxae.

Thorax: Pronotal length $0.25 \mathrm{~mm}$; width across humeri $0.58 \mathrm{~mm}$; mesonotum completely covered by pronotum; metanotum with angles broadly exposed; pronotum slightly convex, coarsely and shallowly pitted, lateral margins broadly rounded, anteriorly convergent. Legs moderately long, covered with pale hairs, fore tibia with short comb (4). Measurements of legs as follows:

$\begin{array}{lcccc} & \text { Femur } & \text { Tibia } & \text { Tarsal 1 } & \text { Tarsal 2 } \\ \text { Anterior } & 27 & 22 & 13 & \\ \text { Middle } & 30 & 30 & 6 & 10 \\ \text { Posterior } & 36 & 40 & 7 & 11\end{array}$

Abdomen: Tergite 1 with narrow (1) transverse sulcus bordering pronotum; length of abdominal tergites I-VII, 10:9:8:7:6:8:13; first genital segment protruding from tergite 7 by $0.15 \mathrm{~mm}$, emarginate apically; maximum abdominal width $0.67 \mathrm{~mm}$ across tergite 3 ; connexiva moderately broad (8), slightly raised, lateral margins evenly slightly convex. Abdomen slightly flattened medially on ventrites 6 and 7, slightly depressed laterad from flattened region; segment 7 with a deep excavation posteriorly (fig. 1); genital segments formed as shown in figure 1; parameres not visible.

Apterous Female: Similar to male in general appearance, but with connexiva vertical anteriorly becoming reflexed over ventrites 6 and 7 ; body somewhat more robust.

Size: Male: Length $1.70 \mathrm{~mm}$; width $0.67 \mathrm{~mm}$. Female: Length $1.87 \mathrm{~mm}$; width $0.70 \mathrm{~mm}$.

Material examined: Holotype ( $\hat{0})$, Allotype (), and paratypes $2 \hat{\jmath} \widehat{o}, 1 \uparrow$, Venezuela, Cueva Alfredo Jahn Miranda, 21.2.1968, Bordon, Strinati. All material 
is deposited in the Museum of Natural History of Geneva, except two paratypes $(\hat{\jmath}, q)$, which are in the Polhemus Collection.

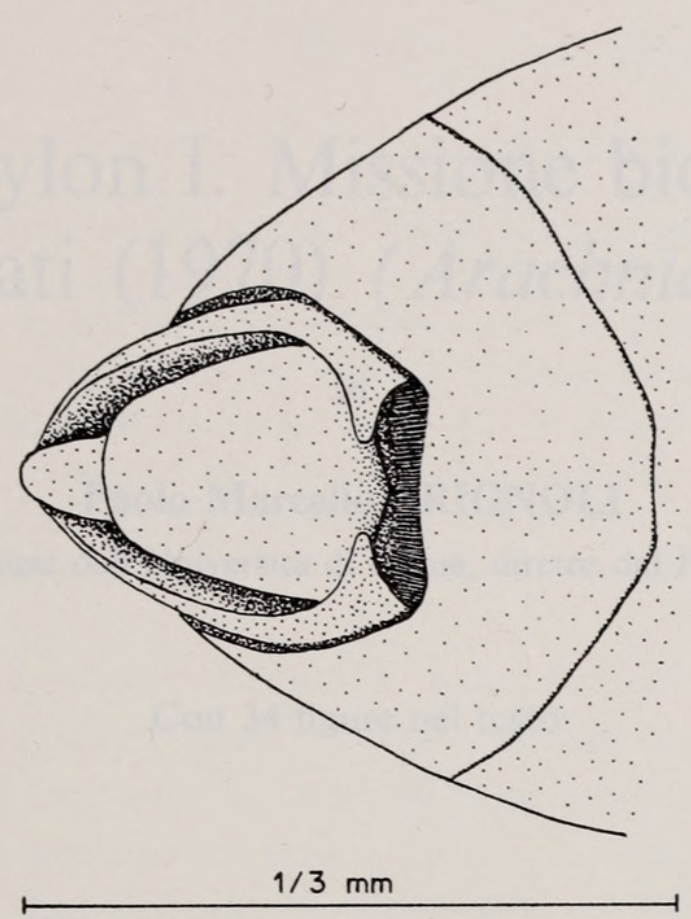

FIG. 1.

Microvelia cavernula n. sp., ventrite 7 and genital segments.

Diagnosis : Microvelia cavernula n. sp. belongs to the group of Microvelia in which the pronotum completely covers the mesonotum. It most closely resembles M. ioana Drake and Hottes 1952, however the latter differs in having the lateral margins of the pronotum constricted medially whereas in cavernula they are evenly rounded. The male of ioana is not known, but the deep excavation between ventrite 7 and the genital segments seems to be unique to cavernula.

\section{REFERENCES}

BAcon, J. A. 1956. A taxonomic study of the genus Rhagovelia (Hemiptera, Veliidae) of the Western Hemisphere, Kans. Univ. Sci. Bull. 38 (1): 695-913.

Drake, C. J. and F. C. Hottes. 1952. New Neogean water-striders of the genus Microvelia. Bull. So. Calif. Acad. Sci. 51 (2): 63-67. 


\section{$2 \mathrm{BHL}$ Biodiversity Heritage Library}

Polhemus, John T. 1972. "Notes on veliids from Venezuela. with the description of a new Microvelia (Hemiptera)." Revue suisse de zoologie 79, 903-905. https://doi.org/10.5962/bhl.part.97142.

View This Item Online: https://www.biodiversitylibrary.org/item/138635

DOI: https://doi.org/10.5962/bhl.part.97142

Permalink: https://www.biodiversitylibrary.org/partpdf/97142

\section{Holding Institution}

American Museum of Natural History Library

\section{Sponsored by}

BHL-SIL-FEDLINK

\section{Copyright \& Reuse}

Copyright Status: Public domain. The BHL considers that this work is no longer under copyright protection.

Rights Holder: Muséum d'histoire naturelle - Ville de Genève

This document was created from content at the Biodiversity Heritage Library, the world's largest open access digital library for biodiversity literature and archives. Visit BHL at https://www.biodiversitylibrary.org. 